\title{
Plasma concentrations of testosterone in the developing ram in different social environments
}

\author{
A. W. Illius, N. B. Haynes, K. Purvis and G. E. Lamming \\ Department of Physiology and Environmental Studies, University of Nottingham \\ School of Agriculture, Sutton Bonington, Loughborough, Leicestershire LE12 5RD, U.K.
}

\begin{abstract}
Summary. Plasma testosterone profiles were determined by taking frequent blood samples at intervals from birth to 21 months of age from rams reared in isolation, in an all-male group and in a mixed-sex group. The testosterone pattern was not modified by these different social environments. The ability of the ram to copulate when first exposed to an oestrous ewe, apparently a maturational process, was also independent of social rearing. At birth plasma testosterone levels were detectable but low, they were higher at 10 and 16 weeks of age and showed a marked rise by 26 weeks, coincident with the time of puberty. Depressive effects of season on testosterone profiles occurred during the 2 nd year of life but not the 1 st year.
\end{abstract}

\section{Introduction}

Recently it has been demonstrated for several species that peripheral plasma levels of testosterone show marked fluctuations over relatively short periods. In the adult ram, up to 10 peaks of testosterone have been observed in $24 \mathrm{hr}$, with levels fluctuating from $<1 \mathrm{ng}$ to $25 \mathrm{ng} / \mathrm{ml}$ plasma, and seasonal variability in testosterone levels has been reported (Attal, 1970; Katongole, Naftolin \& Short, 1974; Purvis, Illius \& Haynes, 1974; Sanford, Winter, Palmer \& Howland, 1974). It has been suggested that individual rams may be characterized by differences in their frequency and level of testosterone peaks since these tended to be consistent within animals when testosterone profiles were measured on different occasions (Purvis et al., 1974).

Plasma testosterone levels are altered by copulation in males of a number of species, e.g. rabbit, bull, man, rhesus monkey and rat (Saginor \& Horton, 1968; Katongole et al., 1971; Fox, Ismail, Love, Kirkham \& Loraine, 1972; Rose, Gordon \& Bernstein, 1972; Purvis \& Haynes, 1974). In bulls, the changes are marked in 3-6-year-old animals but less evident from 1.5 to 2.5 years of age (Smith, Mongkonpunya, Hafs, Convey \& Oxender, 1973). In the adult ram, testosterone levels were unaffected by copulation (Purvis et al., 1974), but the experiments were conducted in March when plasma testosterone levels were seasonally low.

The intention of the present study was to establish when episodic secretion of testosterone first became evident in the ram and to examine the development of testosterone profiles from an early age until maturity, thus providing a basis for the investigation of the role of testosterone in the development of male social behaviour. Further, the experiments were designed to test the hypothesis that the observed differences in testosterone profiles between adult rams could result from different social environments during development. Finally, the animals were used to investigate in more detail the effect of copulation on plasma testosterone profiles.

\section{Materials and Methods}

\section{Animals and rearing procedure}

Twenty Hampshire $\times$ Clun rams born during February 1973 were used. Four treatments were designed to provide extremes of social environment. Five rams were reared artificially from 2 until 
40 days of age using milk substitute and subsequently maintained in individual isolation (Group I, Rams 1-5). Five rams were reared naturally until 6 weeks of age, then kept in isolation after weaning (Group II, Rams 6-10). After weaning at 6 weeks of age, 5 rams were kept together in an all-male group (Group III, Rams 11-15) and 5 were placed with 3 female lambs of the same age to make a mixed-sex group (Group IV, Rams 16-20). At 9 months, the females were separated from the rams by a hurdle. All animals were kept in controlled-environment rooms with the temperature and light adjusted weekly to correspond to external seasonal conditions. A concentrate diet was fed and hay and water were always available. Body weight was recorded weekly. Rams were examined at intervals for penis development using the criterion of Wiggins \& Terrill (1953) of the separation of the glans penis and processus urethrae from the prepuce.

\section{Blood sampling}

Blood was taken from lambs up to 8 weeks of age by jugular venepuncture. All other samples (2-3 ml) were taken from indwelling polythene cannulae (Portex Ltd) introduced into the jugular vein under local anaesthesia, and rams were allowed an overnight acclimatization period before blood samples were taken. After each collection the cannula was flushed with $5 \%$ aqueous sodium citrate solution. Blood was transferred into heparinized tubes and centrifuged at $1500 \mathrm{~g}$ for $20 \mathrm{~min}$ immediately after collection. The plasma was removed and stored at $-20^{\circ} \mathrm{C}$ until required for assay.

Samples were taken hourly for $6 \mathrm{hr}$ at various ages from birth to 8 weeks. At approximately 10, 16, 26 and 38 weeks and 12 and 15 months of age, blood samples were taken every $30 \mathrm{~min}$ for 12-, 18- or 24 -hr periods commencing at 08.00 hours. Samples were also taken at 18 and 21 months of age after the animals had been regrouped. At the latter age, sampling commenced between 16.00 and 19.00 hours. During copulation studies, blood was collected at 30-min intervals from $2 \mathrm{hr}$ before to $6 \mathrm{hr}$ after exposure to the ewe except for the 1st hr after exposure when samples were collected every $10 \mathrm{~min}$.

\section{Copulation studies}

On the basis of testosterone profiles obtained (below) it was decided that Groups I and II should be combined for this study. Nine rams ( 3 from Group IV, 3 from Group III and 3 from Groups I and II) were each allowed contact for $30 \mathrm{~min}$ with an ovariectomized ewe brought into oestrus by injection of $100 \mu \mathrm{g}$ oestradiol benzoate following a 10-day treatment with a progesterone pessary (Synchromate: G. D. Searle \& Co., Bucks). Each animal was tested on 5 occasions between December 1973 and February 1974. They were again tested on two occasions in May 1974, at a time when testosterone levels were assumed to be seasonally low (Katongole et al., 1974; Purvis et al., 1974). Five other rams ( 2 from Group IV and 3 from Groups I and II) were first exposed to an adult oestrous female at this time. Copulation was recorded as successful if the ram achieved intromission and ejaculation.

\section{Assay of testosterone}

This was carried out as described previously for rams by Purvis et al. (1974).

\section{Results}

Statistical evaluations were by analysis of variance or $t$ test unless otherwise stated.

Plasma testosterone profiles for 4 lambs sampled at various times between birth and 8 weeks of age are shown in Table 1. It is apparent that low, but fluctuating, levels of testosterone occur at an early age. Seventeen profiles were obtained in total; fluctuations were present in all, with levels ranging from 0.2 to $4 \mathrm{ng}$ testosterone $/ \mathrm{ml}$ plasma. The development of testosterone profiles for 3 animals up to 38 weeks of age (in October) is illustrated in Text-fig. 1. Peak levels of testosterone increased up to 38 weeks. 


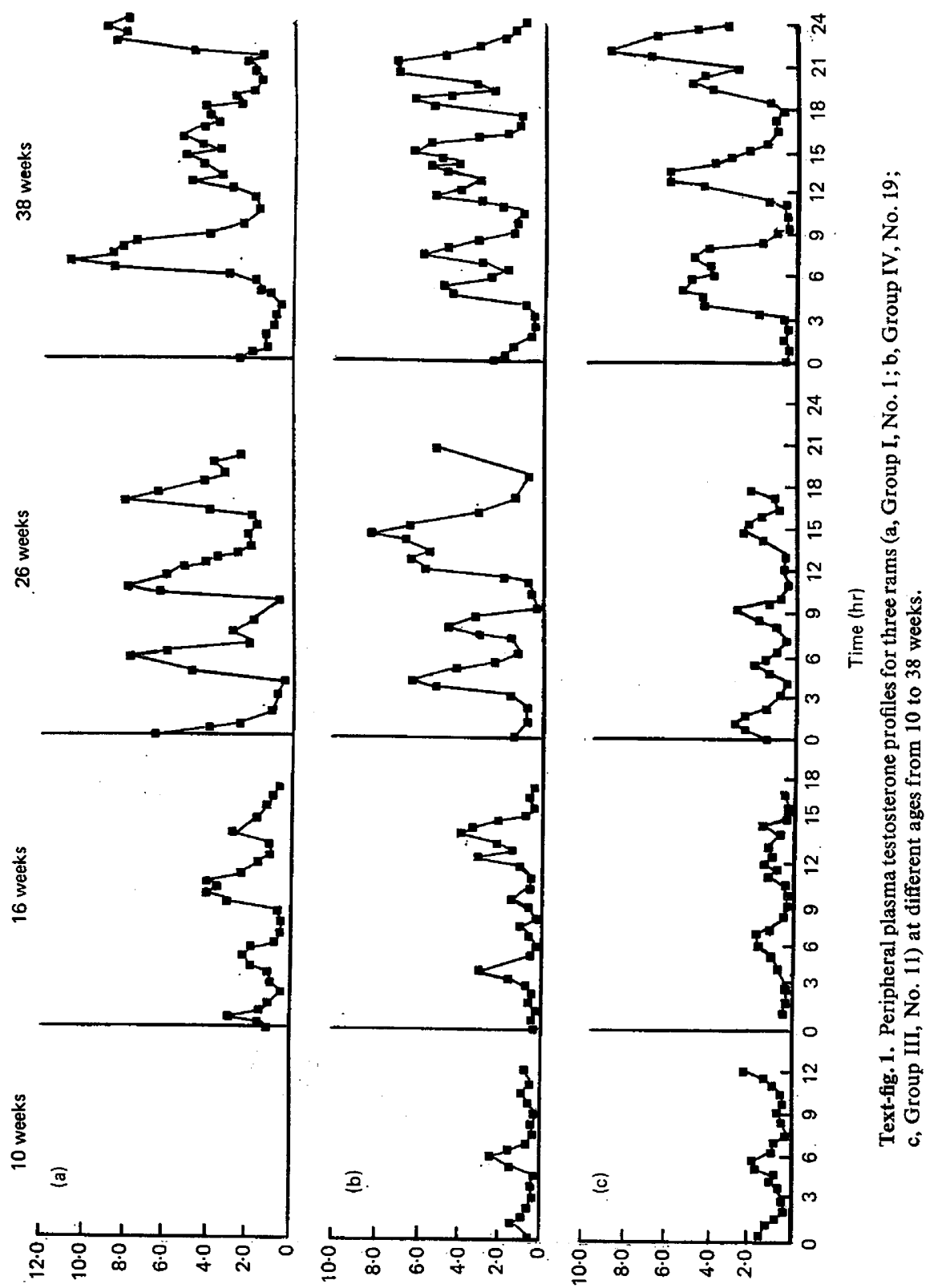

(jw/6u) әuодә]solsə] euseld 
Table 1. The concentrations of peripheral plasma testosterone $(\mathrm{ng} / \mathrm{ml})$ over $6 \mathrm{hr}$ in four ram lambs at different ages

\begin{tabular}{|c|c|c|c|c|c|c|c|}
\hline \multirow[b]{2}{*}{ Age } & \multicolumn{7}{|c|}{ Time (hr) } \\
\hline & 0 & 1 & 2 & 3 & 4 & 5 & 6 \\
\hline \multicolumn{8}{|l|}{ Birth } \\
\hline $\begin{array}{l}\text { (Group III; Ram 13) } \\
6 \text { weeks }\end{array}$ & 0.4 & 0.7 & $1 \cdot 3$ & $0 \cdot 3$ & $0 \cdot 3$ & $1 \cdot 4$ & $1 \cdot 1$ \\
\hline 6 weeks & $1 \cdot 6$ & $2 \cdot 2$ & 0.4 & $0 \cdot 3$ & 0.2 & 0.2 & 0.2 \\
\hline $\begin{array}{l}\text { (Group IV; Ram 19) } \\
8 \text { weeks }\end{array}$ & $2 \cdot 0$ & 1.5 & 1.0 & $1 \cdot 0$ & $2 \cdot 6$ & $2 \cdot 8$ & $2 \cdot 1$ \\
\hline (Group III; Ram 15) & $4 \cdot 4$ & $1 \cdot 8$ & $0 \cdot 3$ & $0 \cdot 2$ & $0 \cdot 2$ & $0 \cdot 5$ & 0.8 \\
\hline
\end{tabular}

Mean height of testosterone peaks, mean testosterone peak intervals and mean testosterone profile areas (adjusted to equalize the length of the sampling period) for all groups at sampling periods between 10 weeks and 21 months of age are shown in Table 2. There were no significant differences between any of these parameters at any given time as a result of the social groupings. Combining the data for all groups, the mean testosterone profile areas for May, August and November 1974 were significantly higher $(P<0.01, P<0.05$ and $P<0.01$ respectively) than the corresponding values for June, August and October 1973, respectively. Furthermore, the mean testosterone profile area for February 1974 was significantly lower $(P<0.05)$ than the values for October 1973 and May 1974, but that for August, 1974 tended to be lower than that for May 1974 and was significantly lower $(P<0.01)$ than that for November 1974. However, the profile area for August 1973 was significantly higher than that for June $1973(P<0.05)$. The mean testosterone peak interval was significantly greater $(P<0.05)$ for February 1974 than at any other time. The testosterone profile areas for individual animals at particular liveweights up to 38 weeks of age are illustrated in Text-fig. 2 . These results show that a marked increase in plasma testosterone concentration takes place between 30 and $40 \mathrm{~kg}$ liveweight, which is reached at about 20 weeks of age.

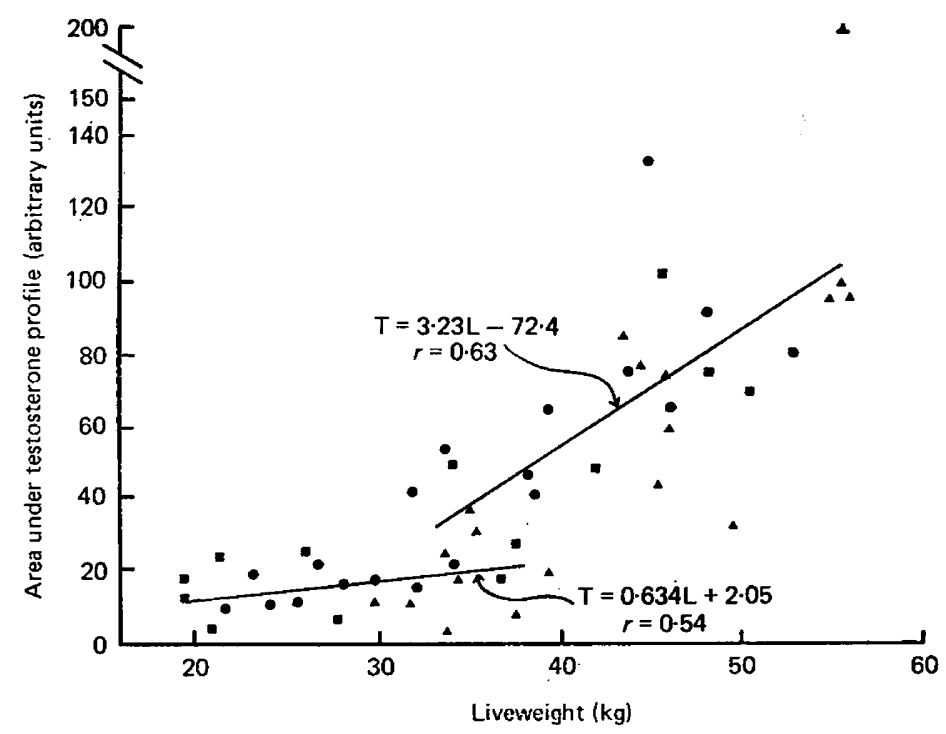

Text-fig. 2. A plot of the areas under the testosterone profiles for individual animals up to 38 weeks of age against liveweight. Since sampling periods varied from 12 to $24 \mathrm{hr}$, all values have been adjusted to a 24-hr period. A, Groups I + II (isolation); $\mathbf{a}$, Group III (all male); $\bullet$, Group IV (mixed sex). 


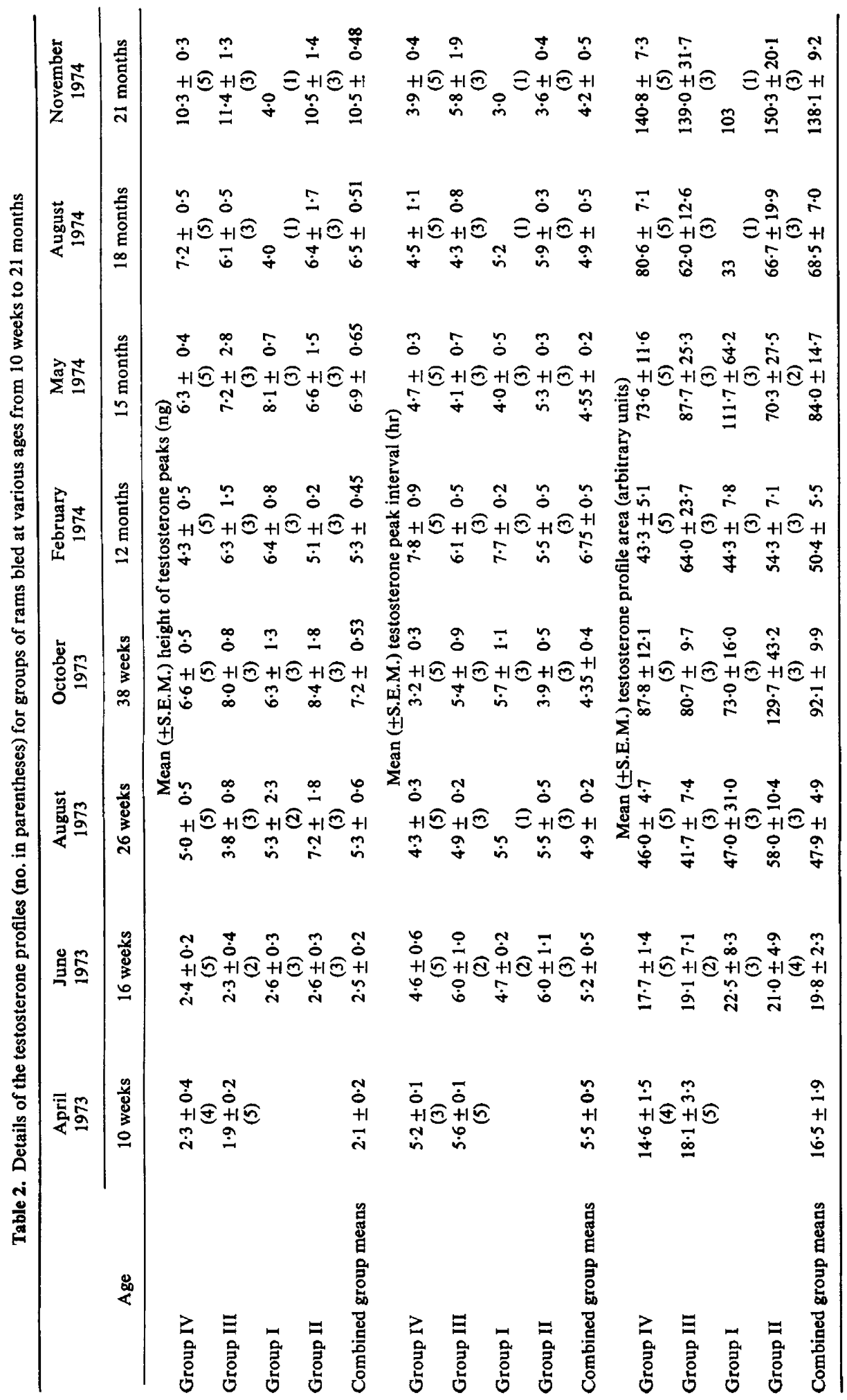


Table 3. The copulation (C) record of individual rams during 7 periods of exposure (see text for details) to an oestrous ewe

\begin{tabular}{|c|c|c|c|c|c|c|c|}
\hline & \multicolumn{7}{|c|}{ Exposure period } \\
\hline & $\begin{array}{c}1 \\
\text { (Dec) }\end{array}$ & $\begin{array}{c}2 \\
\text { (Jan) }\end{array}$ & $\begin{array}{c}3 \\
\text { (Jan) }\end{array}$ & $\begin{array}{c}4 \\
\text { (Feb) }\end{array}$ & $\begin{array}{c}5 \\
\text { (Feb) }\end{array}$ & $\begin{array}{c}6 \\
\text { (May) }\end{array}$ & $\begin{array}{c}7 \\
\text { (June) }\end{array}$ \\
\hline \multicolumn{8}{|l|}{ Group I/II } \\
\hline Ram 1 & - & C & C & $\mathbf{C}$ & C & - & - \\
\hline Ram 4 & - & - & - & - & - & C & C \\
\hline Ram 10 & - & - & - & - & - & C & C \\
\hline Ram 6 & & & & & & C & - \\
\hline $\operatorname{Ram} 7$ & & & & & & C & C \\
\hline Ram 3 & & & & & & - & - \\
\hline \multicolumn{8}{|l|}{ Group III } \\
\hline Ram 11 & $\mathrm{C}$ & - & - & - & - & C & C \\
\hline Ram 12 & - & - & - & - & - & - & - \\
\hline Ram 13 & - & - & - & - & - & C & C \\
\hline \multicolumn{8}{|l|}{ Group IV } \\
\hline Ram 16 & & & & & & C & C \\
\hline Ram 17 & & & & & & - & - \\
\hline Ram 18 & - & - & C & C & C & $\mathrm{C}$ & C \\
\hline $\operatorname{Ram} 19$ & $\mathrm{C}$ & $\mathrm{C}$ & C & C & C & $\mathrm{C}$ & C \\
\hline Ram 20 & - & - & - & - & - & - & C \\
\hline
\end{tabular}

The outline of the copulation experience of the animals in each group is shown in Table 3. Of 9 animals tested on 5 occasions between December and March, only 4 copulated, but each group was represented. The lack of effect of social grouping was maintained during the later exposure periods, in which most of the rams copulated. Forty-five testosterone profiles were obtained during the exposures. Typical examples are shown in Text-fig. 3. The profile shown in Text-fig. 3(a) shows no apparent effect of copulation on testosterone levels; 17 profiles were in this category, but only 3 were obtained when animals copulated. There were 12 profiles of the type represented in Text-fig. 3(b), 4 from copulating animals. The high testosterone levels before exposure to a female may have precluded the possibility of an immediate response. In the 7 animals, 2 copulating, in which the profiles resembled

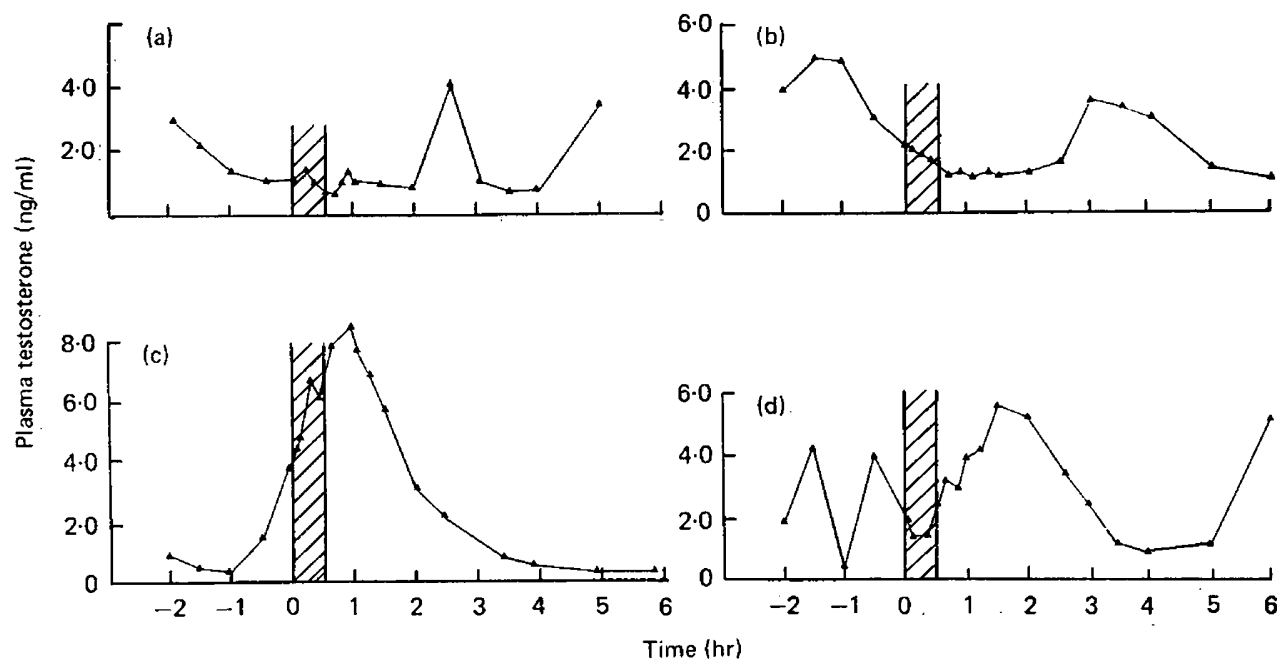

Text-fig. 3. Typical testosterone profiles of individual rams exposed to an oestrous ewe for 30 min (hatched area). 
that shown in Text-fig. 3(c), testosterone levels were rising before exposure and any effect of exposure could have been masked. There were 4 copulating rams in the 9 that exhibited a testosterone profile like that in Text-fig. 3(d), which shows a possible increase in testosterone levels as a result of exposure to females. A $\chi^{2}$ analysis showed that the number of profiles falling into these categories did not differ significantly from the expected random distribution of testosterone peaks. In some cases, an animal which had copulated at a previous exposure had high testosterone levels at the time of a subsequent exposure to a female but did not copulate.

\section{Discussion}

The differences in social environment imposed in these studies did not appear to affect the developing patterns of peripheral plasma testosterone in the young ram since statistical analysis failed to show differences in frequency of plasma testosterone peaks, peak heights or profile areas at ages from 10 weeks to 15 months as a result of social environment. Furthermore, the development of sexual behaviour did not appear to be modified by social grouping; few animals copulated at 10 months, whilst the majority did so at $\mathbf{1 5}$ months, even those given their first exposure to a female at this age. Libido has been reported to be sub-optimal in rams at this season (see Yeates, 1954; Pepelko \& Clegg, 1965). Our results support the observations of Katongole et al. (1974) and Purvis et al. (1974) that adult rams will show apparently normal copulation at times when testosterone levels are known to be low.

There is no evidence from the present study that testosterone profiles of young rams are affected by copulation, irrespective of social rearing, but it is intended to repeat the observations on these animals when they are older because of the differences reported between young and old bulls (Smith et al., 1973).

To assess testosterone changes during development, these have been reduced to a single parameter, namely the area under the profile. Although this value is a resultant of a complex of metabolic variables which cannot be separated, it gives a useful comparative indication of the amount of testosterone secreted by the animal over a given period. Plasma testosterone levels were low but detectable before 8 weeks of age and fluctuations in testosterone levels were apparent at this time. Foster (1974) has observed fluctuations in plasma testosterone following peaks of endogenous plasma LH in rams of this age. The levels then rose, in non-linear fashion, towards adult values by 38 weeks of age. This pattern accords with that found for testis growth in similar ram lambs by Illius, Haynes \& Lamming (1976). The marked change in the rate of increase in testosterone levels occurring as the animals reached $30-40 \mathrm{~kg}$ liveweight, around 20 weeks of age, agrees well with the average liveweights and ages at puberty reported by Dyrmundsson \& Lees (1972) for Clun Forest rams. The criterion of penis development used by Wiggins \& Terrill (1953) was fulfilled by 16 weeks of age in the present study. These authors showed that testosterone was involved in the breakdown of preputial adhesions and the low levels of circulating testosterone before 16 weeks of age are obviously sufficient for completion of this maturation.

The change of testosterone levels in plasma as rams mature apparently represents an interaction between maturational and seasonal variables. The significantly higher levels of testosterone found in August and November 1974 compared to similar periods in 1973 show that testosterone levels increase until at least 21 months of age. The seasonal modification of testosterone patterns is affected by the maturational trend as shown by the different patterns of testosterone secretion in the 1st and 2nd years of life; in 1974 testosterone levels were low in February, increased in May and low again in August, but in 1973 there were no such changes and the levels continued to increase from April to October. It could be argued that immature rams are insensitive to seasonal effects, but this is unlikely since Courot, de Reviers \& Pelletier (1972) have shown differences in LH secretion from birth up to 80 days in lambs born in September or February/March, and Attal (1970) has noted that the seasonal cycle in plasma testosterone is partly masked by testicular growth during the 1st year of a ram's life.

The depression of plasma testosterone levels in February 1974 is partly a result of testosterone peaks occurring at less frequent intervals than at other times of the year; Katongole et al. (1974) have 
reported that LH discharge is less frequent at times when testosterone levels in the ram are seasonally low.

The reason for an elevation of testosterone levels in May and August 1974 compared to February 1974 in the present study is not clear, especially since Katongole et al. (1974) report that values for testosterone in adult rams are consistently low between January and September and high from October to December as a result of changing photoperiod. It may be that maturational effects during the spring and summer in the 2nd year of the animal's life are still interacting with seasonal depressive effects. However, in one 4-year-old ram a seasonal depression in testosterone found in March was not evident by June (Purvis et al., 1974). Also, there are indications from the data presented by Katongole et al. (1974) that the seasonal fall in plasma testosterone levels in the adult ram between January and September is less pronounced in April-June. Pelletier (1971) reports a seasonal increase in ram testicular size in June, and a diphasic increase in testosterone levels in roe deer coming into the breeding season, very similar to that observed for rams in the present paper, has been reported by Gimenez, Borth, Hoffman \& Karg (1975). The subject of photoperiodic control of testicular function in the ram is under further investigation.

This work was carried out during tenure of a Ministry of Agriculture, Fisheries and Food Postgraduate Scholarship (A.W.I.).

\section{References}

AtTal, J. (1970) Measure des oestrogènes et des androgènes testiculaires et plasmatiques dans l'éspece ovine par des micromethodes de chromatographie en phase gazeuse: influence de l'âge de la saison et du cycle diurne. Thèse de Doctorat D'Etat Es-Sciences Naturelles.

Courot, M., de Reviers, M.M. \& Pelletier, J. (1972) Pituitary $\mathrm{LH}$ and blood LH in the male lamb. J. Reprod. Fert. 31, 497-498.

DYRmundsson, O.R. \& LeES, J.L. (1972) Pubertal development of Clun Forest ram lambs in relation to time of birth. J. agric. Sci., Camb. 79, 83-89.

FosTER, D.L. (1974) Regulation of gonadotrophins during foetal and early post-natal development in the sheep. INSERM 32, 143-156.

Fox, C.A., ISmail, A. A.A., Love, D.N., KirKham, K.E. \& Loraine, J.A. (1972) Studies on the relationship between plasma testosterone levels and human sexual activity. $J$. Endocr. 52, 51-58.

Gimenez, T., Borth, D., Hoffmann, B. \& Karg, H. (1975) Blood levels of testosterone in the roe deer, Capreolus capreolus, in relationship to the season. Acta endocr., Copenh., Suppl. 193, 59, Abstr.

Illius, A.W., Haynes, N.B. \& Lamming, G.E. (1976) Effects of ewe proximity on plasma testosterone levels and behaviour in the ram. J. Reprod. Fert. 48, 25-32.

Katongole, C.B., Naftolin, F. \& Short, R.V. (1971) Relationship between blood levels of luteinizing hormone and testosterone in bulls and the effects of social stimulation. J. Endocr. 50, 457-466.

Katongole, C.B., Naftolin, F. \& Short, R.V. (1974) Seasonal variations in blood luteinizing hormone and testosterone levels in rams. $J$. Endocr. 60, 101106.

Pelletier, J. (1971) Infuence du photopériodisme et des androgènes sur la synthèse et la libération de $\mathrm{LH}$ chez le Bélier. Thèse de Doctorat D'Etat Es-Sciences Naturelles.

Pepelko, W.E. \& Clegg, M.T. (1965) Influence of season of the year upon patterns of sexual behaviour in male sheep. J. Anim. Sci. 24, 633-637.

Purvis, K. \& HaYnes, N. B. (1974) Short-term effects of copulation, human chorionic gonadotrophin injection and non-tactile association with a female on testosterone levels in the male rat. J. Endocr. 60, 429-439.

Purvis, K., Illius, A. W. \& Haynes, N.B. (1974) Plasma testosterone concentrations in the ram. J. Endocr. 61, 241-253.

Rose, R.M., Gordon, T.P. \& Bernstein, I.S. (1972) Plasma testosterone levels in the male rhesus: influences of sexual and social stimuli. Science, N.Y. 178, 643-645.

SAGINoR, M. \& Horton, R. (1968) Reflex release of gonadotrophin and increased plasma testosterone concentration in male rabbits during copulation. Endocrinology 82, 627-630.

SANFORd, L.M., Winter, J.S.D., PAlmer, W.M. \& Howland, B.E. (1974) The profile of LH and testosterone secretion in the ram. Endocrinology 95, 627631.

Smith, O.W., Mongkonpunya, K., Hafs, H.D., ConveY, E.M. \& OXENDER, W.D. (1973) Blood serum testosterone after sexual preparation or ejaculation, or after injections of LH or prolactin in bulls.J. Anim. Sci. 37, 979-984.

Wiggins, E.L. \& Terrill, C.E. (1953) Variation in penis development in ram lambs. J. Anim. Sci. 12, 524.

Yeates, N.T.M. (1954) Daylight changes. In Progress in the Physiology of Farm Animals, vol. 1, pp. 362390. Ed. J. Hammond. Butterworths, London. 